\title{
Zeit im Gödelschen Universum
}

\author{
Heinz Rupertsberger, Wien
}

Die Existenz einer globalen Zeit wurde bereits 1905 durch die spezielle Relativitätstheorie von Albert Einstein eingeschränkt. Mit seiner allgemeinen Relativitätstheorie 1915 legte er die Grundlage für die moderne Kosmologie. Es dauerte jedoch 34 Jahre bis Gödel durch seine kosmologische Lösung von Einsteins Feldgleichungen der Gravitation bewies, dass Lösungen mit akausalem Verhalten nicht ausgeschlossen sind. Das Gödelsche Universum wird daher als erstes Beispiel einer Kosmologie, in der es keine globale Zeitordnung der Ereignisse gibt, beschrieben und mit experimentellen Daten verglichen.

\section{Einleitung}

Die Vorstellung der Existenz einer absoluten Zeit, durch die alle RaumZeitpunkte, bzw. Ereignisse in diesen, eindeutig zeitlich geordnet werden können, wie sie u.a. Newton vertrat, wurde bereits durch die spezielle Relativitätstheorie eingeschränkt. Eine ihrer beiden Grundlagen sind das Postulat der Konstanz der Lichtgeschwindigkeit, d.h. jeder Beobachter misst im Vakuum für Licht (stellvertretend für elektromagnetische Wellen) die gleiche Geschwindigkeit. Zusammen mit dem Postulat, dass es kein ausgezeichnetes Inertialsystem gibt, also physikalische Gesetze für alle Beobachter, die sich relativ zueinander mit konstanter Geschwindigkeit und damit kräftefrei (erstes Newtonsches Axiom) bewegen, gleich aussehen, ergibt sich als Konsequenz, dass Raum und Zeit nicht mehr getrennt voneinander betrachtet werden können. In diesem 4-dimensionalen sogenannten RaumZeit Kontinuum gibt es allgemeines Einverständnis über die zeitliche Aufeinanderfolge zweier Ereignisse nur dann, falls ein Signal, das höchstens mit Lichtgeschwindigkeit läuft, zumindest prinzipiell vom früheren zum späteren gesendet werden kann. Der frühere Raum-Zeitpunkt kann dann, zumindest im Prinzip, den späteren beeinflussen, sie sind kausal verknüpfbar. Es gibt also keine Umkehr von Ursache und Wirkung, die Kausalität bleibt gewahrt. Der Begriff der Gleichzeitigkeit verliert jedoch seine Bedeutung, da in einem Bezugssystem gleichzeitige Ereignisse wegen der Endlichkeit 
der Lichtgeschwindigkeit nie kausal verknüpft sein können. Was für den einen Beobachter gleichzeitig ist, wird von einem relativ dazu bewegten Beobachter als nicht gleichzeitig gesehen und die Aufeinanderfolge von kausal prinzipiell nicht verknüpfbaren Ereignissen kann sich für verschiedene, relativ zueinander gleichförmig bewegte Beobachter, sogar umkehren. Weiterhin misst jedoch jeder Beobachter in seinem System räumliche Abstände mit einem Maßstab und zeitliche mit einer Uhr. Die zeitlichen und räumlichen Beiträge zum Abstand zweier Ereignisse in der 4-dimensionalen Raum-Zeit, der für alle Beobachter gleich ist, unterscheiden sich durch ein Vorzeichen und einen relativen Faktor der Lichtgeschwindigkeit zum Quadrat. Es ist daher keineswegs so, dass Raum und Zeit nicht voneinander unterschieden sind, aber die absolute Zeit und der von dieser unabhängige absolute Raum eines Newton existieren seit der speziellen Relativitätstheorie zumindest in der Physik nicht mehr.

\section{Raum-Zeitstruktur in der allgemeinen Relativitätstheorie}

In der speziellen Relativitätstheorie ist die Struktur der Raum-Zeit, in der Ereignisse beschrieben werden, vorgegeben und daher die in ihr herrschende Kausalität bzw. eingeschränkte zeitliche Ordnung problemlos global beschreibbar. Das ändert sich wesentlich in der allgemeinen Relativitätstheorie. Einstein postulierte, dass lokal, d.h. in kleinen Raum-Zeit Bereichen, die Bewegung in einem beschleunigten Bezugssystem nicht von der in einem Gravitationsfeld unterschieden werden kann (Äquivalenzprinzip). Ein im Gravitationsfeld frei fallender Beobachter stellt daher ein Inertialsystem dar, da alle Körper im Schwerefeld gleich schnell fallen und daher keine Geschwindigkeitsunterschiede durch dieses hervorgerufen werden können. Das gilt aber nur lokal, da im Allgemeinen das Schwerefeld vom betrachteten Raum-Zeitpunkt abhängt. Davon ausgehend gelangte er zu der Vorstellung, dass die Massenverteilung oder allgemeiner die Energie-Impuls-Dichte die Quelle der Raum-Zeit Struktur ist, genauso wie in der Elektrodynamik die Ladungen als Quellen das zugehörige elektromagnetische Feld erzeugen. Damit wird aus der pseudo-Euklidischen, ebenen Raum-Zeit der speziellen Relativitätstheorie die pseudo-Riemannsche, gekrümmte der allgemeinen Relativitätstheorie. Dieser Übergang ähnelt in zwei Dimensionen dem von einer Ebene zur Oberfläche einer Kugel oder einer anderen gekrümmten Fläche, wobei „pseudo“ noch den diffizilen Un- 
terschied zwischen Raum- und Zeitkoordinaten andeutet. Der kräftefreien Bewegung auf Geraden im ebenen Raum entspricht die Bewegung auf geodätischen Linien im gekrümmten Raum, im speziellen Fall der Kugeloberfläche auf Großkreisen. Raum und Zeit können nun nicht mehr getrennt von der Materieverteilung bzw. Energie-Impuls-Dichte betrachtet werden, sie sind durch die Einsteinschen Feldgleichungen der allgemeinen Relativitätstheorie miteinander verbunden. Die beschleunigte Bewegung in der Newtonschen Gravitationstheorie im flachen Raum wird zur kräftefreien Bewegung auf einer geodätischen Linie im gekrümmten Raum, auf ihr bewegen sich frei fallende Beobachter. Gleichzeitig wird damit das Problem der instantanen Newtonschen Fernwirkungstheorie der Gravitation aufgelöst. Dafür geht die Überschaubarkeit der globalen Raum-Zeit Struktur, wie sie in der speziellen Relativitätstheorie noch gegeben ist, verloren.

\section{Vereinfachungen für kosmologische Lösungen der allgemeinen Relativitätstheorie}

Es lag natürlich von Anfang an nahe, auch unser Universum mit Hilfe der Einsteinschen Feldgleichungen zu beschreiben. Die Galaxien mit ihren Sternen, schwarzen Löchern usw. erzeugen dann über ihre Energie-Impuls-Dichte unsere Raum-Zeit Geometrie. Die Lösung der Feldgleichungen würde dann sowohl die Vergangenheit wie auch die Zukunft unseres Universums angeben. In dieser Allgemeinheit ist das jedoch aussichtslos. Erstens müsste die Verteilung der Energie-Impuls-Dichte des Universum als Quelle global und für alle Zeiten bekannt sein und zweitens wären die Gleichungen für diese ungeheure Zahl von Objekten, die sich unter dem Einfluss der Gravitation bewegen, viel zu kompliziert. Es sind daher drastische Vereinfachungen bezüglich der Energie-Impuls-Dichte Verteilung des Universums notwendig. Jede auf diese Weise erhaltene Lösung wird als kosmologische bezeichnet und ist von Interesse, da aufgrund der nichtlinearen Struktur der Feldgleichungen selbst bei einfachsten Annahmen keineswegs alle Lösungen im Allgemeinen bekannt sind. Daher kann jede mögliche Effekte andeuten, oder Hinweise dazu liefern, welche zusätzlichen Forderungen zu verlangen sind, um eine dem realen Universum entsprechende kosmologische Lösung zu finden, die mit den experimentellen Daten übereinstimmt. Zunächst werden Einflüsse der drei anderen fundamentalen Wechselwirkungen, der elektro-schwachen und der starken, vernachlässigt, da sie entweder nur kurzreichweitig oder wegen der 
in Übereinstimmung mit experimentellen Daten angenommenen Ladungsneutralität des Universums zu keinen langreichweitigen Kräften führen. Die Mittelung über Distanzen, die groß im Vergleich zum Abstand der Galaxien des Universums sind, ersetzt dessen zunächst diskrete Struktur durch eine stetige Energie-Impuls-Dichte Verteilung. Es entsteht das Bild einer strömenden Flüssigkeit mit entsprechender Druck- und Dichteverteilung, die durch die Gleichungen der relativistischen Hydrodynamik beschrieben wird. Es gibt keinen Grund dafür, einen Punkt des Universums, also auch nicht unser Sonnensystem, als irgendwie ausgezeichnet anzusehen. Daher wird zusätzlich angenommen, dass das Weltall homogen ist, das heißt es sieht überall gleich aus. Diese Annahme wird als kosmologisches Prinzip bezeichnet. Eine inselförmige Materieverteilung mit Vakuum rundherum würde z.B. dieses Prinzip verletzen.

\section{Das Gödelsche Universum}

Aufgrund dieser Vereinfachungen wurden im Rahmen der allgemeinen Relativitätstheorie verschiedenste kosmologische Modelle entwickelt, so zuerst schon 1917 von Einstein selbst (Einstein 1917). Doch erst 1949 gelang es Gödel (Gödel 1949) durch seine exakte kosmologische Lösung mit einer vollständigen Beschreibung ihrer globalen Struktur zu beweisen, dass die allgemeine Relativitätstheorie im Allgemeinen keine Aussage über die Existenz einer absoluten Zeitkoordinate macht, die eine eindeutige Bestimmung der zeitlichen Ordnung von im Prinzip kausal verknüpfbaren Ereignissen ermöglicht. Im Gödelschen Universum sind Zeitreisen in die Vergangenheit möglich, d.h. man kann ausgehend von einem Raum-Zeitpunkt zu diesem oder vor diesem zurückkommen, sozusagen seine eigene Geburt sehen bzw. beeinflussen. Vergangenheit und Zukunft können nicht mehr eindeutig definiert werden.

Die Grundlagen für diese kosmologische Lösung kann man folgendermaßen beschreiben. Die Materie wird durch eine ideale, druckfreie Flüssigkeit, eine Art kosmischer Staub, die rotiert aber nicht expandiert, dargestellt. Diese Rotation sieht für jeden Beobachter, der sich mit der Materie des Universums bewegt, die in diesem Modell geodätischen Linien folgt, gleich aus, alle sehen die gleiche konstante Winkelgeschwindigkeit. Sie kann mit Hilfe eines Foucaultschen Pendels, das sich mit der Materie sozusagen frei fallend mitbewegt, gemessen werden. Aufgrund des Trägheitsgesetzes kann sich seine Pendelebene nicht ändern und damit die Drehung der Pendele- 
bene relativ zur lokalen Umgebung beobachtet werden. Die Situation ist ähnlich der eines Beobachters in einem Satelliten mit Ellipsenbahn um die Erde. Die Ellipsenbahn entspricht einer geodätischen Linie im Schwerefeld der Erde, der Beobachter ist daher in einem frei fallenden Zustand und damit in einem lokalen Inertialsystem. Aber die Schwingungsebene eines Pendels wird sich während eines Umlaufs um die Erde für diesen Beobachter um $360^{\circ}$ drehen. Durch die Rotation ist eine Richtung, die Drehachse, ausgezeichnet und gleichzeitig Bewegung in Form der Drehung vorhanden. Daher ist dieses Universum anisotrop, d.h. es sieht nicht nach allen Richtungen gleich aus, sondern eben nur homogen und auch nicht statisch, aber stationär, es bietet für alle Zeiten den gleichen Anblick. Es kann also nicht unser Weltall darstellen, da es im Widerspruch zur experimentell beobachteten Expansion der Raum-Zeit steht. Das war auch der Anlass für Gödels zweite allgemeinere Arbeit über rotierende Universen (Gödel 1950), in der jedoch keine weiteren expliziten Lösungen angegeben werden. Die Vorstellung liegt nahe, dass eine Rotation, die auch die Zeitkoordinate betrifft, die kausale Struktur einer Raum-Zeit im Großen zerstören kann. Um so erstaunlicher ist es, dass in vorhergehenden Arbeiten, die den Einfluss rotierender Massen auf die Raum-Zeit Geometrie untersuchten, dieser Aspekt nicht diskutiert wurde (Thirring 1918, Stockum 1937). Dieser sogenannte Thirring-Lense Effekt ist erst vor kurzem experimentell durch Beobachtung der Bahnen zweier Satelliten um die Erde bestätigt worden (Ciufolini 2004). Es gab auch schon einige Zeit vor Gödel zumindest eine exakte kosmologische Lösung mit Rotation (Lanczos 1924), die aber weder die globale Raum-Zeitstruktur noch die Rotation diskutierte. Gödel hat vermutlich höchstens von den Arbeiten Thirrings gewusst, da er ja zur relevanten Zeit in Wien studierte und arbeitete. In seiner Vorlesung in Princeton 1949 wird allerdings nur Gamow mit dem Vorschlag, dass das gesamte Universum sich in einem Zustand der gleichförmigen Rotation befindet, namentlich erwähnt (Gödel 1949b). Die Rotation wirkt gegen die Gravitationsanziehung. Beide zusammen reichen jedoch noch nicht für einen Gleichgewichtzustand aus, sodass Gödel noch eine kosmologische Konstante hinzufügen musste. Diese wurde bereits von Einstein (Einstein 1917) für seine kosmologische Lösung eines statischen, räumlich endlichen aber unbegrenzten Universums benötigt und war für ihn ein Teil der Raum-Zeit Geometrie. Bei Gödel steht sie jedoch auf der selben Seite der Feldgleichungen wie die Energie-Impuls-Dichte des Universums und wird damit zu einer Quelle der Raum-Zeit. Das entspricht auch dem derzeitigen Ver- 
ständnis, dass die kosmologische Konstante u.a. die quantenmechanische Vakuumenergie und/oder so genannte dunkle Materie repräsentiert. Wird die Energie-Impuls-Dichte eines Universums durch die relativistische Hydrodynamik beschrieben, dann kann eine kosmologische Konstante stets durch Umdefinition der Dichte- und Druckverteilung in diesen Größen absorbiert werden. Im Fall von Einstein bedeutet das einen konstanten negativen Druck, was jedoch noch nichts über seine Auswirkungen aussagt, da es zunächst nur auf Druckunterschiede ankommt. In der allgemeinen Relativitätstheorie bewirkt ein konstanter negativer Druck eine Expansion der Materie, also eine Art Antigravitation, die im Einsteinschen statischen Kosmos der anziehenden Schwerkraft entgegen wirkt. Also genau das Gegenteil einer Implosion, die man zunächst mit negativem Druck verbinden würde. Bei Gödel hat die kosmologische Konstante im Gegensatz zu Einstein einen negativen Wert, entspricht also einem positiven konstanten Druck und wirkt daher anziehend, verstärkt also die Schwerkraft. Sie ist offensichtlich zusätzlich notwendig, um das durch die Rotation hervorgerufene Auseinanderstreben der Materie zu stabilisieren. Als der expandierende Charakter des Universums an Hand der Rotverschiebung der Spektrallinien entfernter Galaxien experimentell nachgewiesen wurde, hat Einstein diese ad hoc eingeführte kosmologische Konstante wieder verworfen. Theoretisch kann über ihr Vorzeichen kaum etwas ausgesagt werden. Nimmt man an, dass sie durch die quantenmechanische Vakuumenergie entsteht, so tragen Fermionen, Teilchen mit halbzahligem inneren Drehimpuls, negativ und Bosonen, Teilchen mit ganzzahligem inneren Drehimpuls, positiv zu ihr bei. Lange Zeit dominierte die Annahme einer verschwindend kleinen kosmologischen Konstanten, worin man auch eine weitere Begründung für die Existenz der Supersymmetrie für Elementarteilchen sah, d.h. jedes bekannte Fermion hat einen supersymmetrischen bosonischen Partner und umgekehrt. Daher erhält man in einer supersymmetrischen Theorie insgesamt keinen Beitrag der quantenmechanischen Vakuumenergie zur kosmologischen Konstanten. Allerdings hat man bis heute keinerlei Anzeichen für diese durch die Supersymmetrie geforderten neuen Teilchen gefunden. Die derzeitigen experimentellen Daten über eine starke Expansion der Raum-Zeit haben jedoch zu einer Wiedereinführung einer positiven kosmologischen Konstanten, der Antigravitation von Einstein, geführt.

Unabhängig vom konkret betrachteten Universum wird jedem Ereignis sein zugehöriger Raum-Zeitpunkt zugeordnet. Physikalisch mögliche Bewegungen entsprechen dann der kontinuierlichen Aufeinanderfolge solcher 
Raum-Zeitpunkte, den sogenannten zeitartigen Weltlinien, mit der Eigenschaft, dass in jedem Punkt die Geschwindigkeit kleiner als die, oder für masselose Teilchen gleich der Lichtgeschwindigkeit sein muss. Im Spezialfall der kräftefreien Bewegung in der gekrümmten Raum-Zeit erfolgt die Bewegung auf den entsprechenden zeitartigen geodätischen Linien. Da die Lichtgeschwindigkeit die größtmögliche Signalgeschwindigkeit darstellt, beschränken Lichtstrahlen lokal in einem Raum-Zeitpunkt den Bereich, der diesen beeinflussen kann, also die Vergangenheit, sowie auch den, der von diesem beeinflusst werden kann und damit seine Zukunft. Das gilt jedoch in der allgemeinen Relativitätstheorie im Allgemeinen nur mehr lokal, da Lichtstrahlen zwar speziellen geodätischen Linien entsprechen, aber eben in einer gekrümmten Raum-Zeit. Im Gödelschen Universum sieht nun zunächst alles relativ harmlos aus. Der Raum besitzt in einer Richtung eine ebene, euklidische Struktur, daher kann diese bei der Untersuchung der kausalen Struktur vernachlässigt werden. Zur Beschreibung dieses Universums wird das bereits von Gödel angegebene Koordinatensystem, über das in der allgemeinen Relativitätstheorie ja frei verfügt werden kann, verwendet. In diesem verlaufen die geodätischen Materieweltlinien parallel zur gewählten Zeitkoordinate, es wird der Standpunkt eines mit der Materie mitschwimmenden Beobachters gewählt. Es sind alle zeitartigen geodätischen Linien bekannt, sie sind unendlich ausgedehnt und schneiden sich selbst nie im selben Raum-Zeitpunkt. Es stellt sich heraus, dass jede dieser Geodäten, die von einem Raum-Zeitpunkt der Materieweltlinie ausläuft, nach endlicher Zeit wieder zu dieser zurückkehrt, nachdem sie ein endliches Raumgebiet durchlaufen hat. Am weitesten können sich Lichtstrahlen entfernen, die damit die maximale räumliche Distanz bestimmen, die man sich auf einer geodätischen Bahn von der Materieweltlinie entfernen kann. Alle Lichtstrahlen ausgehend von einem Punkt der Materieweltlinie laufen später wieder in einem Punkt dieser zusammen. Sie erzeugen damit für den Beobachter auf der Materieweltlinie einen kreisförmigen optischen Horizont, von außerhalb diesem Gebiet können von ihm keine Lichtsignale empfangen werden. Innerhalb dieses Bereichs gibt es eine eindeutige, durch die Materieweltlinie des Beobachters bestimmte Zeitrichtung für alle Bewegungen. Untersucht man nun wie Lichtstrahlen ausgehend von Raum-Zeitpunkten außerhalb des optischen Horizonts für den Beobachter auf der Materieweltlinie aussehen (die er natürlich nie sehen kann), so stellt man fest, dass plötzlich Bewegungen möglich sind, die relativ zu seiner Zeitrichtung in die Vergangenheit zeigen. Nur beschleunigte Bewegungen, z.B. mit einer Rakete, 
können den optischen Horizont durchbrechen. Dann kann es zu überraschenden Effekten kommen. Startet man mit einer Rakete von einer Materieweltlinie und überschreitet den optischen Horizont, so kann man zu einer benachbarten gelangen, bevor diese ein gleichzeitig vom selben Punkt ausgesendeter Lichtstrahl erreicht. In gewissem Sinn eine Reise mit Überlichtgeschwindigkeit in die Zukunft, Informationen können rascher als das Licht übermittelt werden (Pfarr 1981). Diese Art von Zukunftsreise hat nichts mit dem Effekt der Zeitdilatation durch eine beschleunigte Bewegung bzw. in einem Gravitationsfeld zu tun, führt aber noch immer nicht zu akausalen Verhältnissen. Entfernt man sich jedoch von einer Materieweltlinie auf einer beschleunigten Bahn weiter als dem Durchmesser des optischen Horizonts, so erscheinen die dort lokal ausgestrahlten Lichtstrahlen derart verzerrt, dass zeitartige Weltlinien möglich werden, die zum selben oder sogar zu einem früheren Zeitpunkt der ursprünglichen Materieweltlinie zurückkehren. Damit ist bewiesen, dass die allgemeine Relativitätstheorie Universen zulässt, in denen aufgrund der globalen Geometrie der Raum-Zeit die Kausalität verletzt wird. Zeitreisen in die Vergangenheit werden möglich mit allen damit zusammenhängenden Problemen, wie u.a. der schon erwähnten Frage, ob man seine eigene Geburt verhindern kann. Diese geometrischen Verhältnisse werden z.B. in (Rupertsberger 2002) veranschaulicht.

\section{Größenordnungen und Schlussbemerkungen}

Um eine Vorstellung über die involvierten Größenordnungen zu bekommen, kann man für den einzigen freien Parameter dieses Universums den gegenwärtigen Wert der Materiedichte unseres Universums einsetzen. Für eine volle Umdrehung wird etwa das zehnfache des gegenwärtigen Alters des Universums benötigt, der optische Horizont hat etwa die Größe des Durchmessers des Universums, falls man nur das Alter desselben zur Abschätzung heranzieht. Die kosmologische Konstante entspricht dem etwa $10^{-15}$-fachen des normalen Luftdrucks auf der Erde. Man kann sich nun für Zeitreisen die Erde als Rakete vorstellen, deren Materie als Treibstoff dient, der mit Lichtgeschwindigkeit ausgestoßen wird. Dann ergibt eine äußerst grobe Abschätzung, dass für eine Reise von einer Materieweltlinie um 100 Jahre in die Vergangenheit derselben bei einer Reisedauer von 100 Jahren mindestens soviel Materie verbraucht wird, dass die Erde am Schluss der Reise auf eine Kugel mit etwa 6m Radius geschrumpft ist. Um die astronomischen Entfernungen in der kurzen Zeit von nur 100 Jahren zurücklegen 
zu können, sind zusätzlich Reisegeschwindigkeiten extrem nahe der Lichtgeschwindigkeit notwendig (Pfarr 1981). Diese Größenordnungen zeigen die Schwierigkeiten real funktionierende Zeitmaschinen, falls sie überhaupt möglich sind, zu konstruieren, ändern jedoch nichts an der Tatsache, dass sie innerhalb der Voraussetzungen der allgemeinen Relativitätstheorie nicht ausgeschlossen werden können. So konnte auch die Antwort Einsteins auf die kausalen Probleme in Gödels Lösung nur lauten: „Es wird interessant sein zu erwägen, ob diese nicht aus physikalischen Gründen auszuschließen sind" (Einstein 1949). Ein wesentlicher Fortschritt zu dieser Bemerkung ist derzeit nicht ersichtlich. Gegenwärtig werden akausale kosmologische Lösungen durch die chronology protection conjecture Anfang 1990 von Hawking (Hawking 1992) ausgeschlossen. Sie besagt, dass die Gesetze der Physik das Auftreten geschlossener zeitartiger Bahnen verhindern. Das wird versucht mit Hilfe von speziellen Beispielen zu belegen, bleibt aber trotzdem nur eine Vermutung.

So entsteht im Rahmen der Physik aus der absoluten, universellen Zeit Newtons der Zeitbegriff der speziellen Relativitätstheorie, der nur mehr für im Prinzip kausal verknüpfbare Ereignisse eine eindeutige Zeitrichtung festlegt, die dann ohne weitere Zusatzannahmen in der allgemeinen Relativitätstheorie global nur mehr abhängig vom speziell betrachteten Universum existiert oder verschwindet.

\section{Literatur}

Ciufolini, Ignazio und Pavlis, Erricos C. 2004 „A confirmation of the general relativistic prediction of the Lense-Thirring effect", Nature, 431, 958-960.

Einstein, Albert 1917 „Kosmologische Betrachtungen zur allgemeinen Relativitätstheorie“, Sitzungsberichte der Preußischen Akademie der Wissenschaften 142-152.

- 1949 „Bemerkungen zu den in diesem Band vereinigten Arbeiten“, in: Paul Arthur Schilpp (Hrsg.), Albert Einstein als Philosoph und Naturforscher, Stuttgart (Kohlhammer) 1955 (engl. Original Evanston IL (Northwestern UP) 1949).

Gödel, Kurt 1949 „An Example of a New Type of Cosmological Solutions of Einstein's Field Equations of Gravitation“, Reviews of Modern Physics $21,447-450$. 
Gödel, Kurt 1949b „Lecture on rotating universes“, in: Solomon Feferman (Hrsg.), Kurt Gödel, Collected Works, vol.3, 269-287.

- 1950 „Rotating Universes in General Relativity Theory“, in: L.M. Graves et al (Hrsg.), Proceedings of the International Congress of Mathematicians, Providence Rh.I.: American Mathematical Society, vol.1, 175-181.

Hawking, Stephen W. 1992 „Chronology protection conjecture“, Physical Review D46/2, 603-611.

Lanczos, Kornel 1924 „Über eine stationäre Kosmologie im Sinne der Einsteinschen Gravitationstheorie“, Zeitschrift für Physik 21, 73-110.

Pfarr, Joachim 1981 „Time Travel in Gödel's Space“, General Relativity and Gravitation 13/11, 1073-1091.

Rupertsberger, Heinz 2002 „Das Gödelsche Universum“, in: Bernd Buldt et al (Hrsg), Kurt Gödel - Wahrheit E̋ Beweisbarkeit, Wien: öbv \& hpt, vol.2, 219-229.

Stockum, W.J. van 1937 „The Gravitational Field of a Distribution of Particles Rotating about an Axis of Symmetry“, Proceedings of the Royal Society of Edinburgh, A 57, 135-154.

Thirring, Hans 1918 „Über die Wirkung rotierender ferner Massen in der Einsteinschen Gravitationstheorie“, Physikalische Zeitschrift, 19, 33. 


\title{
"Close to the Speed of Light": \\ Dispersing Various Twin Paradox Related \\ Confusions
}

\author{
Miloš Arsenijević, Belgrade
}

...I noticed that mathematical clarity had in itself no virtue for Bohr. He feared that the formal mathematical structure would obscure the physical core of the problem, and in any case, he was convinced that a complete physical explanation should absolutely precede the mathematical formulation.

(Heisenberg 1967, p.98)

\section{Introduction}

One century after the appearance of the first of Einstein's several articles about what was later called Special Relativity Theory (SRT), one still cannot say that SRT has been sufficiently conceptually clarified to render concern about the meaning of its key concepts, or about the way in which it explains phenomena, a matter of mere ignorance. Some recent articles can be taken as evidence for this. Let me quote the diagnosis given in one of them, which concerns what Langevin called "The Twin Paradox" (Langevin 1911, p.31), referring to Einstein's original two clocks thought experiment described in "Die Relativitätstheorie” (Einstein 1911, pp.12ff.): “...Students often inquire as to 'why' the accelerated twin ages less and 'when' the extra aging of the home twin occurs. These questions are not well defined in the scientific sense but have promoted a variety of analyses (many can be found on the pages of this journal [American Journal of Physics]) which for most part have been useful additions to the pedagogy of special relativity theory" (Boughn 1989, p.792).

I join Boughn's appreciation of the analyses prompted by the two cited students' questions (see, for instance, Romer 1959, Perrin 1970, Unruh 1981, Good 1982), but, contrary to him, I hold the students' questions themselves perfectly well formulated, directly answerable, and more than vindicated due to the great diversity of answers (or at least of the ways in which "the 
right answer" is formulated), including those given by some great physicists (among them Einstein himself).

In dealing with the two students' questions, we shall come across more explanations of the Twin Paradox that are at least misleadingly formulated if not straightforwardly wrong, and the attempt to disperse the conceptual confusion they cause, or can cause, is the main task of this paper.

\section{A purely phoronomic re-description of the paradox}

Nearly all discussions of the Twin Paradox begin with the problem of symmetry: how can one of the twins turn out to be younger if becoming further from and becoming closer to are symmetrical processes?

Bergson solved the problem of symmetry in the way Alexander the Great had solved the problem of the Gordian knot: there will be no age difference at the end of the trip because the difference in aging during twins' getting apart form each other is compensated by the inverse process during their approaching each other (see Bergson 1976, pp.434ff.).

The standard reaction to Bergson's "solution" is that there is an asymmetry since one of the twins has to slow down and speed up in order to meet his brother. The problem with this answer is that deceleration and acceleration are neither necessary nor sufficient for the explanation of the phenomenon, as we shall see in what follows.

Let us describe the situation purely phoronomically, by stipulating that A's and B's "becoming closer to each other" and "becoming further from each other" have no commitments of "approaching" and "getting apart" in the sense that it is neither implied that it is only A or only $\mathbf{B}$ that is moving, nor that $\mathbf{A}$ and $\mathbf{B}$ are moving in opposite directions, nor that $\mathbf{A}$ is chasing $\mathbf{B}$, nor that $\mathbf{B}$ is chasing $\mathbf{A}$. In this way, it is also left indeterminate whether it is only not said (for whatever reason) what the case de re is or it makes no sense to differentiate de re among the possible cases mentioned because the distinction is not observer-invariant.

Let us suppose that $\mathrm{A}$ and $\mathrm{B}$ were initially becoming closer to each other at a uniform relative speed, and then, at the meeting point, synchronized their clocks. When later B met $\mathbf{C}$ after supposedly becoming closer to him at a speed that was uniform but greater than the speed of A's becoming closer to $\mathbf{B}, \mathbf{C}$ synchronized his clock with B's. After some time, $\mathbf{A}$ and $\mathbf{C}$ must have met. Were their clocks synchronized at the meeting point or not, and if not, is it C's clock or B's clock that was slow relative to the other one? 


\section{Overcoming the underdetermination of the phoronomic re-description in SRT}

The underdetermination of the situation described purely phoronomically follows from the indeterminateness of the directions of motion of $\mathbf{B}$ and $\mathbf{C}$. Is this indeterminateness overcome in SRT even under the assumption that all motion has been uniform since ever?

Let $\mathbf{A}$ and $\mathbf{B}$ be light sources that, by passing each other, emit two light rays in both directions of their relative motion. Unexpectedly for the Newtonian physicist, each two of the four rays that move in the same direction will simultaneously reach any screen put orthogonally to their propagation. The fact that light behaves in this way has been known at least since 1849, when Fizeau performed the famous experiments that Einstein liked to cite (see Einstein 1977, pp.39-41). The three well-known theories explain this behavior of light in the following three ways.

According to the Maxwell-Lorentz's theory, every lightwave propagates in any direction at the same speed with respect to the ether, which means that all the four rays propagate at the same speed with respect to the same point in absolute space from which they were emitted.

Since the ether theory is incompatible with the deeply rooted idea of classical physics that all inertial states of motion are equivalent, Einstein had tried, sometime before 1905, to modify electrodynamics by supposing that the speed of the light source is to be added to the propagating effect, which was later elaborated in Ritz's 1908 emission theory (see Norton 2004, pp.58ff.). According to the emission theory, one cannot refer to a point left behind the moving sources but may say only that each two of the four rays that propagate in the same direction propagate differently with respect to $\mathrm{A}$ and with respect to $\mathbf{B}$.

Re-considering constantly the thought experiment he had been allegedly obsessed with since he was sixteen, which concerns the possibility of chasing a beam of light till the point at which it becomes frozen for the chaser, Einstein finally gave up the emission theory for the three reasons (see Norton 2004, Sections 5-6), one of them being that it does not only allow for the possibility that the light beam be seen as frozen but makes something like this likely to happen, which, however, does not happen. In SRT, this is impossible to happen by definition: light is postulated to propagate, with respect to any source, at the same speed in all directions, which implies, automatically, that it is not possible to catch up with a light beam by chasing it. 
If light propagates at the same speed in all directions, what about the case in which the light sources are moving relative to each other? The only way to avoid contradiction is to accept that the spacetime metric, and so also space-like and time-like metrics, are different in the referential systems of the two sources. This consequence is crucial for overcoming the underdetermination of the phoronomic description of the Twin Paradox, but it is not obvious how it is to be used.

Let us call a property Shakespearean (recalling the famous verse on the rose), be it non-relational or relational, if and only if its true ascription to something is observer-invariant (see Geach 1972, p.139). For instance, if John is shorter than Peter, he will be shorter even if he looks taller (for whatever reason) to an observer, and he will remain shorter even if we start to praise him as taller than Peter. The properties being shorter than and being taller than are relational, but Shakespearean relational properties.

Is direction of motion a Shakespearean property? According to Descartes' metaphysics, motion is always only relative because God, by permanently bringing the world into being, is also the ultimate cause of any change in the world (cf. Descartes 1986, Part II $\S 36,25,27$ ). So, as in a movie, if the position between two bodies is changed, it is not changed because one of them or both moved but because God put them in a different spatial relation. Consequently, though different world stages are real and not just an appearance, motion as such is just an appearance. This is why for the Cartesians the direction of motion can be, and in fact is, a non-Shakespearean relational property.

In SRT, the light propagation is absolute not only in view of the assumed constancy of its speed, which is independent of the motion of light sources, but also because its direction is a Shakespearean property according to the main postulate of SRT: it propagates in the direction in which it is impossible to catch up with it by chasing it. If there were two bodies positioned at the line along which a light beam propagates but at the opposite sides of the light beam, the beam would propagate necessarily in the direction in which it could come across one of the two bodies, and necessarily not in the other direction. But what about the direction of motion of the bodies themselves (as potential or actual light sources)?

The main problem in answering this question follows from the assumption that light propagates always and in all directions at the same speed relative to any light source, so that each light source should be considered to be at rest relative to any ray emitted, while, at the same time, the light sources 
can move, as they often do, relative to each other. Is it then possible to say, or perhaps even necessary to conclude, that the direction of motion of two light sources moving relative to each other is yet a non-Shakespearean property, in spite of the fact that the direction of the light propagation itself is a Shakespearean property?

For the negative answer to the last question it would be sufficient to show that, in some cases at least, the electromagnetic effects will differ according to what we suppose to be the directions of motion of the two light sources involved. Now, the Twin Paradox shows just this, which is one of its two main roles that has never been explicitly mentioned as such. Namely, the situation described in the Twin Paradox is the exemplum crucis for showing that in SRT the direction of motion of the light sources themselves must be a Shakespearean property, which is a good reason for agreeing with Michael Redhead that "the terminology 'relativity' for Einstein's theory is arguably misleading” (Redhead 1993, p.120). The second important role of the Twin Paradox, obvious and recognized, is that it exemplifies the essential difference between SRT and the other two rival theories through some striking consequences that are in principle testable (and have already been tested indirectly — see, for instance, Hafele and Keating 1970).

(a) If $\mathbf{B}$ and $\mathbf{C}$ (in the above phoronomic description) are supposed to move in opposite directions, the average speed of the composite motion of $\mathbf{B}$ and $\mathbf{C}$ must be greater than the speed of $\mathbf{A}$ independently of whether $\mathbf{A}$ and $\mathbf{B}$ move in the same or in opposite directions. Namely, if A and B move in the same direction, then $\mathbf{B}$ is obviously faster than $\mathbf{A}$, and $\mathbf{B}$ and $\mathbf{C}$ are supposed to move at a relative speed that is greater than the relative speed at which $\mathrm{A}$ and $\mathrm{B}$ move. So, the path traversed by $\mathrm{B}$ and $\mathrm{C}$ will be longer than that of $A$, and so their average speed greater than that of $A$. If $A$ and $B$ move in opposite directions, then, however small the relative speed of $\mathbf{B}$ may be, $\mathbf{C}$ will more than balance it by chasing and supposedly reaching $\mathrm{A}$. So, the average speed of the composite motion of $\mathbf{B}$ and $\mathbf{C}$ will be greater again. This means that, because $\mathrm{B}$ and $\mathrm{C}$ were faster than $\mathrm{A}$ in the absolute sense, their average speed was closer to the speed of light when compared with the speed of A. This finally means (by taking into account how the contradiction threatening from the assumption that the speed of light is the same in all directions relative to any source has been avoided) that between the meeting of $\mathbf{A}$ and $\mathbf{B}$ and the meeting of $\mathbf{A}$ and $\mathbf{C}$ the composite time of $\mathbf{B}$ and $\mathbf{C}$ must have been metrically shorter than the time of $\mathrm{A}$, which means in effect that, if A, B, and C emitted light signals periodically according to identical clocks 
synchronized in the described way, the number of signals emitted by $\mathbf{B}$ and $\mathrm{C}$ must have been smaller than the number of signals emitted by $\mathbf{A}$.

(b) It is easy to show, by applying the analogous reasoning, that the outcome will be inverse if we suppose that $\mathrm{B}$ and $\mathrm{C}$ move in the same direction: the time of $\mathbf{A}$ will be shorter than the composite time of $\mathbf{B}$ and $\mathbf{C}$, and the number of signals emitted by $\mathbf{A}$ will be smaller than the number of signals emitted by $\mathbf{B}$ and $\mathbf{C}$.

It follows from $(a)$ and $(b)$ that there will be differences concerning the electrodynamic effects depending solely on whether $\mathrm{B}$ and $\mathrm{C}$ move in opposite directions or in the same direction, which means that, according to SRT, the direction of motion of the light sources must be a Shakespearean property (Q.E.D.).

\section{Einstein's original description of the Clock Paradox and the role of the turning point}

In his description of the Two Clocks Thought Experiment Einstein mentioned a "speed close to the speed of light" twice, the first time when assuming that one of the clocks "moves at a high speed (close to the speed $c$ ) at a uniform motion", the second time by deriving the general conclusion that, in the end, it will turn out that "the position of the hand of the clock almost didn't change during the entire journey" and that, in the analogous case of an organism, "the long journey lasted for just a moment because it moved at a speed close to the speed of light" (Einstein 1911, pp.12-13 [my translation]).

The natural question about Einstein's description is why we need a roundtrip for concluding that the clock that moves back and forth will be slow, given that the conclusion is derived from nothing else but the closeness of its speed to the speed of light and that we have assumed at the very beginning that it is this clock that moves at a speed close to the speed of light.

One could be tempted to say that the round-trip is introduced with the sole intention to shock by its strange result, and this is the first reason why it is better to omit Einstein's assumption about the initial speed of any of the two clocks.

The second reason for omitting the assumption that one of the clocks (or twins) moves at a speed close to the speed of light already by becoming further from the other clock (twin) concerns the generality of the situation described. There is an infinite number of ways in which the round-trip can 
take place with necessarily the same outcome concerning the question of how the clocks are desynchronized at the end. Recalling our phoronomic description, the only additional assumption necessary and sufficient for the conclusion that $\mathbf{C}$ 's clock will turn out to be slow is that $\mathbf{B}$ and $\mathbf{C}$ move in opposite directions. So, Einstein's description is just one very special case.

The third reason for omitting any assumption concerning the initial speed of any of the clocks relative to the speed of light concerns the impossibility of testing any such assumption either during the clocks' receding further from each other alone or during their getting closer to each other alone. As we shall see below, it is only the change in frequency of the received signals that can enable the twins (or $\mathbf{A}$ and $\mathbf{C}$, with the help of $\mathbf{B}$, in our re-description) to calculate what will be the ratio of the number of the sent signals to the number of the received signals, which is necessary for concluding how each traveler has been moving and aging.

In view of the last point, however, it is important to note that the fact that it is not testable how the aging processes are developing while the twins recede further from each other alone and get closer to each other alone does not mean that the final age difference is not the result of the difference in aging. In spite of the fact that Einstein's assumption about the initial speed of a clock is unnecessary, it is certainly not wrong in the sense that it makes no sense to assume something like this. The suggestion that it cannot be said "when" the difference in aging is coming into being, based on the necessity of a turning point for saying anything about the age difference, led to the "mysterious" explanation (we shall come across below) that the age difference takes place instantaneously.

\section{Invoking dynamical factors}

All misleadingly formulated, incomplete or directly wrong solutions to the Twin Paradox are based on a misinterpretation of the role of the turning point on the round-trip.

Lecturing about the Twin Paradox, Feynman said that those who think it is a real paradox do so because they "believe that the principle of relativity means that all motion is relative" (Feynman 1963.p.16-3). What he actually wanted to say is not that they think just that all motion is relative but rather that the direction of motion is an observer-dependent, non-Shakespearean property. Feynman's answer to this Cartesian challenge is that "the man who has felt the acceleration, who has seen things fall against the walls, and so on, 
is the one who would be younger" (loc. cit.). Since Feynman, after having indicated an asymmetry between the twins, didn't explain in which way exactly it is relevant for the difference in aging, his explanation is incomplete. But it is also misleading because deceleration and acceleration are neither necessary nor sufficient for the difference in aging.

Deceleration and acceleration are not necessary because the direction of motion is a Shakespearean relational property according to the main postulate of the SRT, which is sufficient, as we have seen, for the explanation of the difference in aging even in the case in which all motions involved in the experiment are supposed to be uniform.

Deceleration and acceleration are not sufficient for the occurrence of the phenomenon because a twin that has changed direction can still age faster, namely, if the relative speed after he has changed his direction of motion is not sufficient to reach his brother.

In brief, possible dynamical factors related to the turning point are as such not causally responsible for the difference in aging, being at best an indication of which twin will be younger given that he moves at a speed that enables him to reach his brother.

However, arguing against "the orthodox relativists", Whitehead claimed that "acceleration and deceleration (as distinct from uniform velocity) express an essential fact of the life of any body" (Whitehead 1923, p.41), and that it is just "the diverse history" of the body of the chronologer on the earth and of the traveler's body, that is, "the real diversity of relations of their bodies to the universe", that "is the cause of their discordance in time-reckoning" (ibid., p.34).

Similarly, by trying to explain why it is the traveler's clock $U^{\prime}$ that will be slow relative to the earth clock $U$ and not vice versa, Reichenbach invoked "the theory of gravitation", which "shows that the special theory of relativity is applicable only because the distant masses of the fixed stars determine a particular metric field", so that a retardation of $U^{\prime}$ is "the effect of the moving fixed stars, which produce a gravitational field at the instant of the reversal of the motion" (Reichenbach 1956, p. 193). To refute this "solution", it is sufficient to imagine two journeys of the same person, with the same clock, moving at the same speed and turning himself around in the same way at the same cosmic point, with the only difference being that one of them lasts longer (see Mermin 1968, p. 144). The two journeys bring about different age differences, since the age difference depends on the length of the journey, and not on anything that happened at the turning point. 
Finally, Richard Tolman, the most famous of Feynman's predecessors at the California Institute of Technology, claimed that due to the possibility of the symmetrical analyses the paradox "can arise when the behavior of clocks is treated in accordance with the principles of special relativity without making due allowance for the principles of the general theory" (Tolman 1962 , p.194), while it is "readily solved with the help of the general theory of relativity, if we do not neglect the actual lack of symmetry between the treatment given to the clock $A$ which was at no time subjected to any force, and that given to the clock $B$ which was subjected to the successive forces $F_{1}, F_{2}$ and $F_{3}$ when the relative motion of the clocks was changed" (ibid., p.195).

\section{The light signals exchange and the geometric representation of the thought experiment}

As shown in Section 3, the Twin Paradox exemplifies the situation in which we are vindicated in saying that one of the twins (or B and C in our re-description of the situation) moved at an average speed that was closer to the speed of light than was the speed of the other twin (A in our re-description). Ontologically speaking, this fact is ratio essendi for claiming that the number of light signals emitted by the back and forth traveling twin ( $\mathrm{B}$ and $\mathrm{C}$ in our re-description) must have been smaller than the number of the signals emitted by the other twin ( $\mathbf{A}$ in our description) in spite of the fact that the signals were supposedly emitted after the same time intervals had elapsed according to the identically made and synchronized clocks of the twins (of $\mathrm{A}, \mathrm{B}$, and $\mathrm{C}$ in our re-description). But then, the ratio of the total numbers of the signals emitted and received must be ratio cognoscendi for establishing, by the twins ( $\mathrm{A}, \mathrm{B}$, and $\mathrm{C}$ ) themselves, how their trip actually looked in view of the questions of the direction of their motion and of when and how close their motion was to the speed of light.

Let us suppose that, at the time they meet, $\mathbf{A}$ and $\mathbf{B}$ have arranged to send light signals to each other every year. Let them arrange, in addition, that if $\mathbf{B}$ meets or reaches a cosmic wanderer $\mathbf{C}$ moving at a uniform speed, it will be $\mathbf{C}$ who will instead of $\mathbf{B}$ continue to receive and send signals in the arranged way (according to B's clock). Now, due to the Doppler shift, both A and $\mathbf{B}$ will receive signals from each other with a frequency that is less than the frequency of the signals they send. But, the frequency with which the signals are received along with A's and B's knowledge of the relative speed 
at which they recede further from each other will not enable them to say anything about whose speed, if anyone's, is closer to the speed of light. $\mathrm{Mu}$ tatis mutandis, the same holds for $\mathbf{A}$ and $\mathbf{C}$.

However, the fact that neither $\mathrm{A}$ and $\mathrm{B}$ nor $\mathrm{A}$ and $\mathrm{C}$ can get any information about their speed relative to the speed of light on the basis of what was happening during the time $\mathrm{A}$ and $\mathrm{B}$ were receding further from each other alone, and during the time $\mathrm{A}$ and $\mathrm{C}$ are getting closer to each other alone, it does not follow that $\mathrm{A}$ and $\mathrm{C}$ (the latter with the help of $\mathrm{B}$ ) cannot infer what was and what is going on in the absolute sense by calculating, on the base of their frequency, the total number of signals that will be sent and the total number of those that will be received, and finaly by comparing the two. Namely, if $\mathbf{B}$ and $\mathbf{C}$ de facto moved in opposite directions (independently of whether there is any dynamical indication of that or not), then, by the time $\mathrm{A}$ and $\mathrm{C}$ meet, the total number of signals that $\mathrm{A}$ received must be less than the total number of the signals he sent, while the total number of the signals received first by $\mathbf{B}$ and then by $\mathbf{C}$ must be greater than the total number of the signals they sent. If, on the other hand, B and C de facto moved in the same direction, the situation concerning the total numbers of sent and received signals will be the inverse.

The just said can be illustrated through the following two Minkowskian diagrams (borrowed from Bohm 1996, pp. 169, 171).
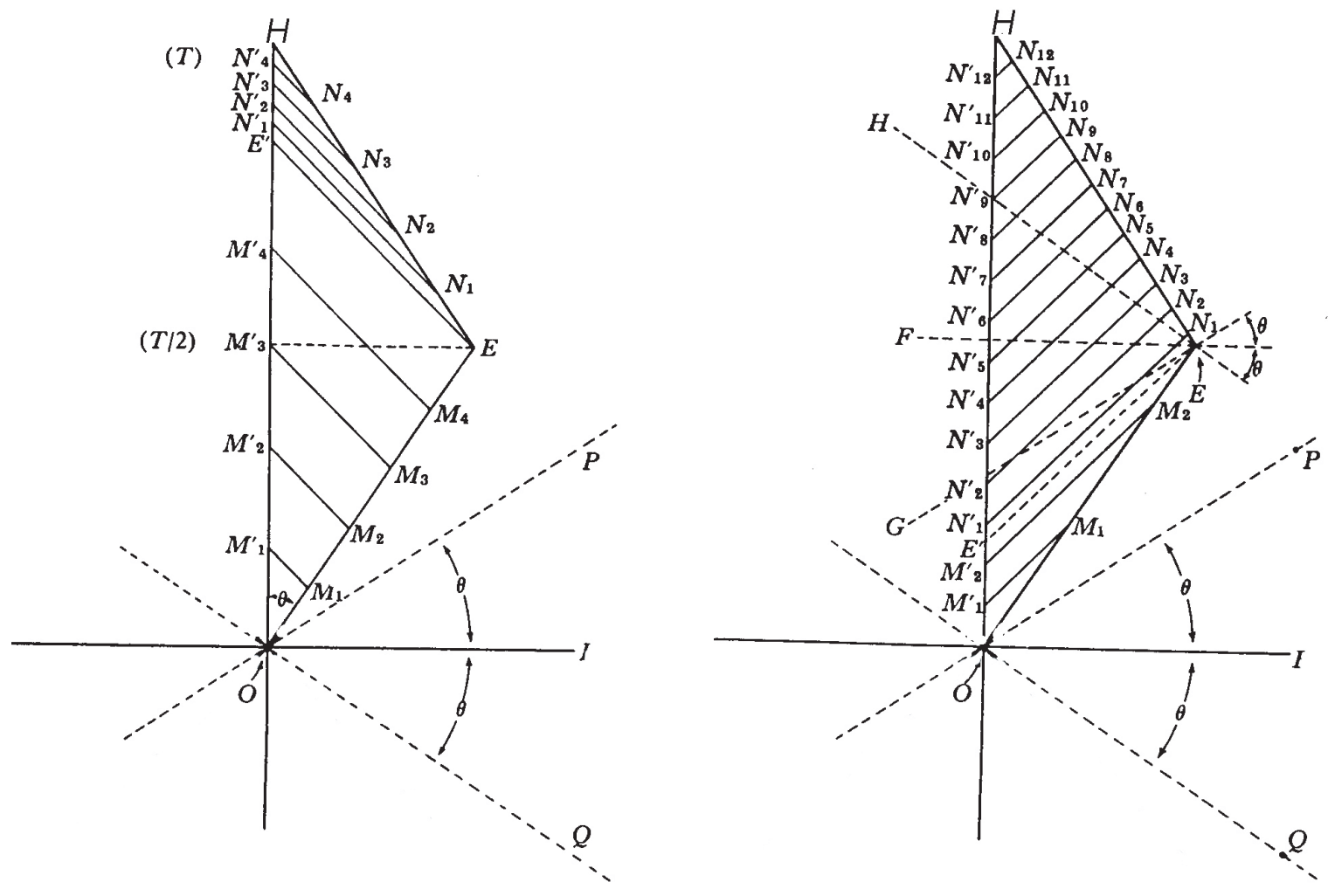
It is important to note that, by drawing these diagrams, Bohm followed Einstein's original description of the thought experiment, according to which A (whose world-line is $\mathrm{OH}$ ) is taken to be at rest while $\mathbf{B}$ (whose world-line is $O E$ ) and $\mathbf{C}$ (whose world-line is $E H$ ) are taken to be moving in opposite directions at the same uniform speed relative to A. That's why $O E$ is equal to $E H$ and why, on the left diagram, the intervals between signals $M_{1}, M_{2}$, $M_{3}$, and $M_{4}$, sent by $\mathrm{B}$, are equal to the intervals between signals $N_{1}, N_{2}, N_{3}$, and $N_{4}$, sent by C. But the point we are interested in would not be lost if we changed these special assumptions, obtaining a triangle of any other shape. The only necessary assumption, without which we wouldn't obtain a triangle at all as the representation of what is going on, is that the speed at which $\mathrm{B}$ and $\mathbf{C}$ move relative to each other is greater than the speed at which $\mathrm{A}$ and $\mathbf{B}$ do so. The additional assumption, not necessary for getting a triangle but necessary for getting $E$ to be the turning point, is that $\mathbf{B}$ and $\mathbf{C}$ move in opposite directions, for the purely phoronomic description allows for the possibility that, by meeting $\mathbf{C}, \mathbf{B}$ actually overtakes $\mathbf{C}$. In this latter case, due to the fact that, after $\mathbf{B}$ and $\mathbf{C}$ meet, it is $\mathbf{C}$ whose time starts being compared with that of $\mathrm{A}$, the turning point would occur at A's world-line, and not at the point where $\mathbf{B}$ and $\mathbf{C}$ meet, for it is now $\mathbf{A}$ who (without doing and feeling anything new!) actually starts chasing $\mathbf{C}$.

Now, it is clear from the left diagram that A will start receiving signals with a greater frequency (than the frequency of the signals he sends) only at $E^{\prime}$, that is, relatively late, so that the total number of received signals will be less than the total number of sent signals. On the other hand, as it is clear from the right diagram, only a few signals sent by $\mathbf{A}$ will be received by $\mathbf{B}$ with a lesser frequency (than the frequency of the signals $\mathbf{B}$ sent), while the rest of signals, sent during a much longer time, will be received by $\mathrm{C}$ with a frequency that is greater than the frequency of the signals sent by $\mathrm{C}$. So, the total number of the signals received by $\mathrm{B}$ and $\mathrm{C}$ will evidently be greater than the total number of the signals sent by them.

Is it at all possible that $\mathrm{A}$ and $\mathrm{C}$ meet finding their clocks synchronized? No, because there is only one turning point. But if we imagine A meeting some fourth person $\mathbf{D}$ under conditions that are completely symmetrical relative to those in which $\mathbf{B}$ meets $\mathbf{C}$, then, when $\mathbf{C}$ and $\mathbf{D}$ met, their clocks would be synchronized. The Minkowskian diagram representing this situation would contain two broken world-lines symmetrical in view of the line connecting the meeting points of $\mathbf{A}$ and $\mathbf{B}$, and $\mathbf{C}$ and $\mathrm{D}$. So, the Bergsonian "solution" is true only in a special case, where there are two turning points. 


\section{When does the difference in aging come into being?}

However nice a device the Minkowski diagram method is for representing geometrically what is going on physically, an understanding of what is going on physically must be the guide for "reading off the diagram".

Since we have explained in physical terms in which way the final age difference of the twins is the result of the difference in aging, which can be but needn't be the same during the whole trip though it must always be in favor of the twin who traveled faster in the absolute sense, we may use Minkowski diagrams to show students when and how exactly the difference in aging came into being. For instance, according to the two diagrams above, which represent Einstein's original description, the final age difference is the result of the difference in aging that was coming into being during the whole trip. Namely (by using again our three persons A, B, and C instead of two twins), it can be directly read off from the left diagram that, if $\mathrm{A}, \mathrm{B}$, and $\mathrm{C}$ arranged to send signals every year, the composite motion of $\mathbf{B}$ and $\mathbf{C}$ lasted 10 years (these 10 years being $O M_{1}, M_{1} M_{2}, M_{2} M_{3}, M_{3} M_{4}, M_{4} E, E N_{1}, N_{1} N_{2}$, $\left.N_{2} N_{3}, N_{3} N_{4}, N_{4} H\right)$, while, as can be read off from the right diagram, $\mathrm{A}$ lived 15 years (these 15 years being $O M^{\prime}{ }_{1}, M^{\prime}{ }_{1} M^{\prime}{ }_{2}, M^{\prime}{ }_{2} N^{\prime}{ }_{1}, N^{\prime}{ }_{1} N^{\prime}{ }_{2}, N^{\prime}{ }_{2} N^{\prime}{ }_{3}, \ldots$, $\left.N^{\prime}{ }_{11} N^{\prime}{ }_{12}, N^{\prime}{ }_{12} H\right)$.

Let us turn to other, less specific triangles, but still with the meeting point of $\mathbf{B}$ and $\mathbf{C}$ as the turning point ( $E$ on the diagram), meaning that both $\mathbf{A}$ and $\mathbf{B}$ must be supposed to be moving, and moving in opposite directions. In this case (in contrast to the example of Einstein and Bohm), the length of B's and C's years must be different, because $\mathrm{C}$ has to chase and catch up with $\mathrm{A}$. The final age difference must again be in favor of $\mathbf{B}$ and $\mathbf{C}$ taken together, but though it can still be true that it is in favor of both $\mathrm{B}$ and $\mathrm{C}$ relative to $A$, it can be also in favor of $A$ over $B$, and $C$ over $A$. The former would be the case if $\mathbf{B}$ were supposed to move, when compared to $\mathbf{A}$, at a speed closer to the speed of light, while the latter would be the case if the speed of A were closer to the speed of light.

\section{A "mysterious" geometric explanation of the age difference}

Though one can find what has just been said evident and even trivial, the students' question of when the difference in aging takes place has been often suggested, as in Boughn's case, not to be well defined. But worse than that, 
Minkowski diagrams are often used to "show" that the faster aging is based on the existence of some "extra time", which another twin saved "instantaneously", which is at best a very misleading façon de parler.

In his famous book Space, Time, and Spacetime, Lawrence Sklar explains the age difference using the following diagram:

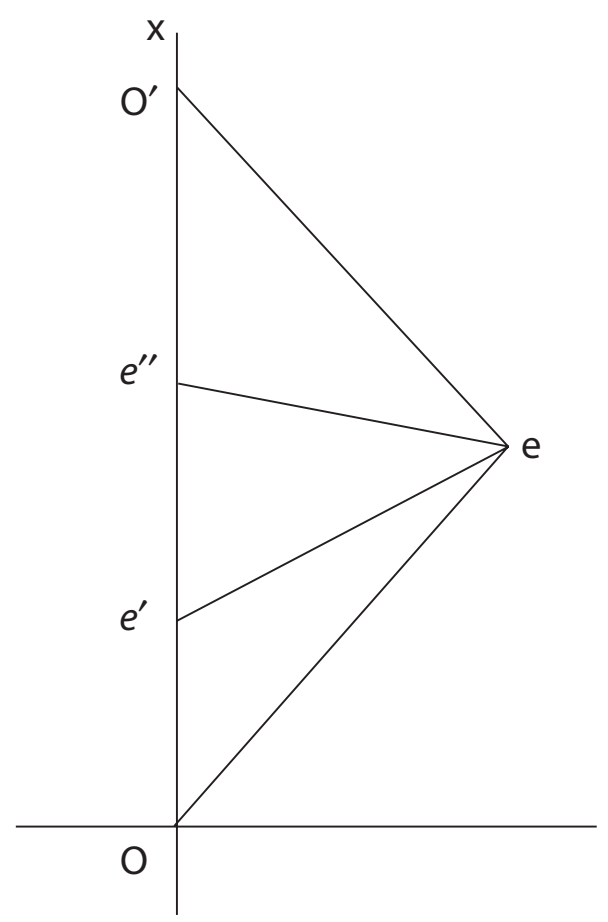

He says: "The accelerated observer calculates that the inertial clock runs slow according to his from $O$ to $e^{\prime}$, and also from $e^{\prime \prime}$ to $O^{\prime}$; but he sees himself as moving instantaneously from one inertial path to the other (at event $e$, his acceleration being 'almost instantaneous'), yet $e$ is simultaneous with $e^{\prime}$ in his first inertial frame, and with $e^{\prime \prime}$ in the second. It is the life of the inertial clock from $e^{\prime}$ to $e^{\prime \prime}$ which makes the inertial clock read a greater time interval from $O$ to $O^{\prime}$ than does the accelerated clock" (Sklar 1977, p.270 [my italics]).

The crucial thing is that Sklar says that the life of the inertial clock is longer due to its life from $e^{\prime}$ to $e^{\prime \prime}$ (which is the interval between events $N_{2}{ }_{2}$ and $N^{\prime}{ }_{9}$ on the right Bohm diagram above, where $O I$, and its parallels, are the simultaneity lines from A's reference system, and $O P$ and $O Q$, and their parallels, simultaneity lines from B's and C's referential systems respective1y). Complementary to this, Sklar says that the accelerated clock saved time at turning point $e$, which is "simultaneous with $e$ ' in his first inertial frame, and with $e^{\prime \prime}$ in the second". Speaking about a similar diagram, Redhead says that it "shows $\beta$ 's [the traveling twin's] clock running ahead of $\alpha$ 's [the oth- 
er one's] along sections $O e^{\prime}$ and $e^{\prime \prime} O$, but mysteriously standing still along $e^{\prime} e^{\prime \prime}$ allowing the differential aging of $\alpha$ to take place" (Redhead 1993, p.123 [letters substituted to fit Sklar's diagram]). I find the adverb "mysteriously" used by Redhead quite appropriate.

By dealing with the Sklarian-style explanation based on the Minkowskian flat spacetime geometry, we are faced with a situation that is strikingly similar to that we were already faced with in Section 5, when we were dealing with the explanations based on dynamical factors. In both cases, the turning point is correctly associated with the twin who will finally turn out to be younger, but some effects of the change of the inertial system, independently of whether accidental or necessary, are wrongly allowed to figure in the explanation, which should be based instead on the difference in metrics alone, as a consequence of the difference in (at least average) speed relative to the speed of light.

If we want to use geometric representation to explain what is going on physically, we have first to use two Minkowski diagrams, in the way in which Bohm did it, for it is only so that we can directly read off, and then compare, the time metric of the accelerated twin shown in terms of the total number of time units during the whole trip (the left Bohm diagram) and the time metric of the other twin shown through the total number of time units of the round-trip (the right diagram). Each of the two diagrams taken per se shows only in which way one of the twins judges the time of the other one.

It is of great importance to notice that the time-distance between $e^{\prime}$ and $e^{\prime \prime}$, which Sklar speaks of as the time saved by the change of the inertial system, depends on both speeds, the one between $O$ and $e$ and the other between $e$ and $O^{\prime}$, which determine the angle at $e$ on the diagram. So, at $e$, the age difference that will show up at the end of the trip is still to come into being through the difference in aging caused by the difference in metrics, which itself is caused by the difference in speed relative to the speed of light. So, it is at least a very misleading façon de parler to say that the accelerated twin saved some time (represented on the diagram as $\left.e^{\prime} e^{\prime \prime}\right)$ by the very act of changing the inertial system.

"The discrepancy between the simultaneity relations" that Wesley Salmon takes to be "the key to the whole problem" (Salmon 1980, p.98) is something that itself should be, and can be, explained through the spacetime metrics of the whole situation. It would be mysterious indeed if the fact that "there is no moment between $e^{\prime}$ and $e^{\prime \prime}$ that the traveling twin could find simultaneous with any moment of his trip" were to mean that the age difference at the 
end of the trip is the result of an extra life that the home twin lived while his brother was (only for an instant!) at the turning point of his trip. But there is nothing mysterious in saying that due to the difference in spacetime metrics, and consequently in metrics of space-like and time-like intervals, the twins not only age differently but also cannot use any simultaneity relation that would be the equivalence relation-from which the "discrepancy" caused by the change of the referential system, which Salmon speaks about, can be derived as a corollary.

\section{Conclusion and consequences: The Twin Paradox in the flat but closed spacetime}

Once it is clearly explained why the twin who turned out younger did (because the metric difference between his and his brother's world-lines favored him due to his speed, which was, on average at least, closer to the speed of light) and when the favoring age difference was coming into being (which can be either during the whole trip or during a part of it only, but in a more than balancing way), the question about the necessity of the turning point becomes answerable without confusion. In the standard representation, we need the turning point for epistemological and operational reasons. Namely, in the open flat Minkowski spacetime, it is only the round-trip that enables us to prove that one of the twins must have been faster in the absolute sense and so "closer to the speed of light". At the same time, it is only the change of one of the twins' inertial systems that brings about the change in the frequency of the received light signals, enabling the twins themselves to calculate metrical differences between their world-lines.

After dispersing all the confusions caused by the insufficiently clarified role of the turning point, we are free to turn to various closed spacetime models and describe the Twin Paradox situation without a turning point, as it is done, for instance, in (Brans and Stewart 1973), (Dray 1982), (Low 1990), (Uzan, Luminet, Lehoucq and Peter 2000). Let me give a nice example that shows what happens in one of these cases.

It is shown above why in the open flat Minkowski spacetime the existence of one turning point implies the asymmetry that is necessary and sufficient for the final difference in age between the twins, whereas, on the other hand, the existence of two symmetric turning points implies that there will be no difference in age between them. What will happen if the twins move at a uniform speed in spacetime that is topologically so structured that it is flat 
but closed, so that it is unnecessary that there is a turning point before the twins meet?

According to the account given above, there can be an infinite number of cases lying between the two extremes. One of these extreme cases is that both twins move at a speed that is equally close to the speed of light. In this case, there will be no difference in aging and, consequently, no difference in the final difference in age between the twins. In the other extreme case, one of the twins is at rest. In this case, he will turn out older at the meeting point. In all other cases, the twin who is moving at a speed that is closer to the speed of light will finally turn out younger. How is the second extreme case to be represented?

The first thing to notice is that the topological structure is supposed to be flat in the sense that its Riemann tensor vanishes identically, so that we can pick a coordinate system in which the metric is constant. This means that we can have a case in which neither twin undergoes acceleration.

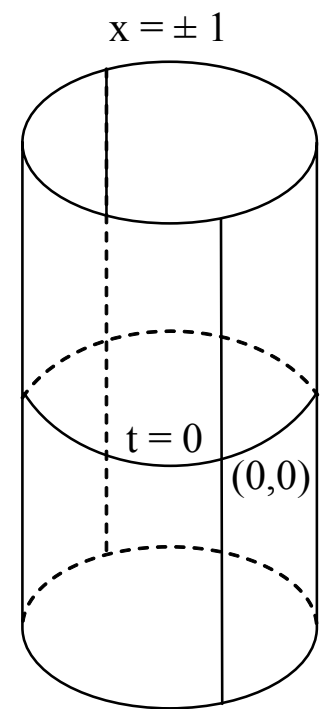

At the same time, however, the topological spacetime structure is supposed to be closed in the sense that there are pairs of space points-say, the point $x=1$ and the point $x=-1-$ which are identical for all values of $t$. This means in effect that, as the geometric Minkowski spacetime representation, we get a cylinder (see the diagram above) with the $t$-axis as the vertical one.

Now, let us suppose that one of the twins remains at rest at $x=0$, while the other starts off at $(0,0)$, moving to the right with relative speed $v$, undergoing no acceleration at any time. This means that, between $(0,0)$ and $(0, \pm 1)$,the former will travel along the $t$-axis only, while the latter will travel along a helix winding round the cylinder with slope determined by $v$. 
When $t=2 / v$ (in the frame of the first twin), the two twins will meet at $(0, \pm 1)$.

It is clear that, in the given case, no resolution in Sklar's style is possible (cf. Section 8 above), since there is no turning point at which the twin traveling along the helix could allegedly save some extra time. Moreover, the original paradox seems to re-emerge because one could argue that both twins can apply Lorentz transformations in the same way during the whole trip and get the same result at the end of the trip (see Low 1990, §2). In other words, if one of them calculates the other's measure of elapsed time by multiplying $2 / v$ by $\sqrt{\left(1-v^{2}\right)}$, so does the other.

Low says that "the entire technology of using Lorentz transformations to calculate is suspect in this context" because "the transformations make sense locally" but not "on the whole" of Minkowski spacetime (ibid., §3). Namely, due to the fact that "spacetime in this instance, although flat, is not simply connected", the twins' receding from each other is, at the same time, their approaching each other. After that, Low claims that it is only the twin who remains at $x=0$ who is right in calculating the other twin's measure of the whole elapsed time by multiplying $2 / v$ by $\sqrt{\left(1-v^{2}\right)}$, because by unwrapping the cylinder and finding various positions of the twins we see that in the frame of the twin who is at rest, for any value of $t$, the departure of the other twin from the corresponding position is always simultaneous, while it is not so in the frame of the twin who travels along the helix.

What Low says is, of course, correct from the point of view of the spacetime geometry. But again, following Bohr's requirement, cited by Heisenberg - that a physical explanation should absolutely precede the mathematical formulation - there is more that needs to be said in order to give a full explanation in physical terms.

Firstly, from the physical point of view, a part of the reason why only one of the twins is right in calculating the measure of the elapsed time of the other twin by multiplying $2 / v$ by $\sqrt{\left(1-v^{2}\right)}$ is that it is supposed, in the given extreme case, that it is he who is at absolute rest relative to the light propagation, so that it is he who is in the absolutely privileged position to calculate any time saved by anybody moving relative to him. It is so, once again, only because in SRT it is not only true, as in the emission theory, that light propagates at the same speed in relation to any light source, but also that it propagates so in an absolute sense, independently of whether one can detect it or not. 
Secondly, another part of the reason why one of the twins is right in calculating the measure of the elapsed time of the other twin by multiplying $2 / v$ by $\sqrt{\left(1-v^{2}\right)}$ is that it is supposed, in the given extreme case, that light itself propagates in such a way that it will finally reach the same space point from which it started off and that the other twin is chasing such a light beam. In other words, the cylindrical spacetime representation, according to which one of the twins travels along a helix, is correct only because light is supposed to propagate in the described way.

Thirdly, the supposed fact that light propagates at the same speed both in an absolute sense as well as in relation to any light source, implies that there must be a difference in both space-like and time-like metrics, which means that traveling along the spacetime helix must be longer in view of space and shorter in view of time. In other words, the difference between the simultaneity relations, which Low draws our attention to, is only the consequence of the difference in metrics and not the other way round.

Finally, the most delicate question, which Low does not address in his article, is how the twins themselves can find out by exchange of light signals, if they can do it at all, what their clocks will show at the end of the trip. They can do that in essentially the same way in which it has been shown that they can do it by traveling in the open Minkowski spacetime. Namely, though in the closed Minkowski spacetime there is no turning point, so that the twins cannot use the difference in frequencies between the signals sent periodically before and after the turning point, they can send and receive signals sent periodically in opposite directions (because the spacetime is supposedly closed) and use the difference in their frequencies for calculating the time that has elapsed and the time that is to elapse before they meet. So, both can apply Lorentz transformations for calculating the whole elapsed time.

All in all, from the physical point of view, the resolution of the Twin Paradox formulated in the closed flat Minkowski spacetime is the same as the resolution of it when formulated in the open flat Minkowski spacetime.

\section{References}

Bergson, H. 1976 "Discussion With Becquerel of the Paradox of the Twins", in: M. Capek (ed.), The Concepts of Space and Time, 433-439. Bohm, D. 1996 The Special Theory of Relativity, Routledge. 
Boughn, S.P. 1989 “The Case of the Identically Accelerated Twins”, Am.J. Phys. 57, 791-793.

Brans, C.H and Stewart D.R. 1973 "Unaccelerated Returning Twin Paradox in Flat Spacetime", Phys. Rev. D8, 1662-1666.

Descartes, R. 1988 Principles of Philosophy, in The Philosophical Writings of Descartes, Vol. I, Cambridge University Press.

Dray, T. 1990 "The Twin Paradox Revisited", Am. J. Phys. 58, 822-825.

Einstein, A. 1911 "Die Relativitätstheorie", Vierteljabrsschrift der naturforschenden Gesellschaft in Zürich.

- 1977 Relativity-The Special and the General Theory, Methuen and Co. Ltd, London (first edition 1920).

Geach, P.T. 1972 Logic Matters, Basil Blackwell.

Good, R.H. 1982 "Uniformly Accelerated Reference Frame and Twin Paradox", Am. J. Phys. 50, 232-238.

Hafele, J.C. and Keating, R.E. 1972 "Around-the-World Atomic Clocks: Observed Relativistic Time Gains”, Science 177, 168-170.

Heisenberg, W. 1967 "Quantum theory and its interpretation", in: S. Rozental (ed.), Niels Boh-His Life and Work as Seen by His Friends and Colleagues, North-Holland, Amsterdam.

Langevin, P. 1911 "L'évolution de l'espace at du temps”, Scientia X (31).

Low, R.J .1990: "An acceleration-free version of the clock paradox", Eur. J. Phys. 11, 25-27.

Mermin, N.D. 1968 Space and Time in Special Relativity, Waveland Press.

Norton, J.D. 2004 "Einstein's Investigations of Galilean Covariant Electrodynamics prior to 1905", Archive for History of Exact Sciences 59, 45-105.

Perrin, R. 1970 "Twin Paradox: A Complete Treatment from the Point of View of Each Twin", Am.J.Phys. 44, 317-319.

Redhead, M. 1993 “The Conventionality of Simultaneity”, in: J. Earman, A.I. Janis, G.J. Massey, N. Rescher (ed.), Philosophical Problems of the Internal and External Worlds, University of Pittsburgh Press, 103-128.

Reichenbach, H. 1956 Philosophy of Space and Time, Dover.

Romer, R.H. 1959 "Twin Paradox in Special Relativity", Am. J. Phys. 27, 131-135.

Salmon, W.C. 1980, Space, Time, and Motion (2nd edition, revised), University of Minnesota Press.

Sklar, L. 1977 Space, Time, and Spacetime, University of California Press, Berkeley, Los Angeles, London. 
Tolman, R. 1962 Relativity, Thermodynamics and Cosmology, Clarendon Press, Oxford (first edition 1934).

Unruh, W.G. 1981 "Parallax Distance, Time, and the Twin Paradox", Am. J. Phys. 49, 589-592.

Uzan, J.-P. , Luminet, J.-P., Lehoucq, R.L. and Peter, P. 2000 “Twin Paradox and Space Topology", Ar. Phys., June, 1-6.

Whitehead, A.N. 1923 "The problem of simultaneity", Aristotelian Society, Suppl. Vol. 3, 34-41. 